\title{
Burnout: The Effects of Demographic Factors on Staff Burnout: An Application at Public Sector
}

\author{
Ahmet Emin Serin ${ }^{1} \&$ Mehmet Onur Balkan ${ }^{2}$ \\ ${ }^{1}$ Faculty of Management, University of Turkish Aeronautical Association, Ankara, Turkey \\ ${ }^{2}$ Bayat Vocational School, Afyon Kocatepe University, Afyon, Turkey \\ Correspondence: Mehmet Onur Balkan, Bayat Vocational School, Afyon Kocatepe University, Afyon, Turkey. \\ Tel: 9-053-2644-9906. E-mail: onur.balkan@gmail.com
}

Received: February 12, 2014

Accepted: March 4, 2014

Online Published: March 26, 2014

doi: 10.5539/ibr.v7n4p151

URL: http://dx.doi.org/10.5539/ibr.v7n2p151

\begin{abstract}
The aim of this paper is which should be considered a descriptive survey in the general sense, to highlight the effects of demographical differences on staff burnout. The related literature on job burnout could largely be found. It is hypothesized that the demographical variables had an effect on job burnout. Maslach burnout inventory was used as a survey in order to measure and assess the job burnout. The survey conducted on 261 employees of a public sector institution. Data, obtained from questionnaires analyzed through the SPSS statistical packaged software. The results show that, the title had a positive and age had a negative and significant effect on depersonalization.
\end{abstract}

Keywords: burnout, emotional exhaustion, depersonalization, personnel achievement

\section{Introduction}

Today's work environment and fundamental changes in workplace and management leads employees to a different and challenging environment. Increased constraints, decreased resources and time limitations makes worker much aggressive.

The existing idea of burnout is viewed as current trend related to difficulties of modern work (Angerer, 2003). "Burnout can be defined as a condition of psychological problems experienced as a result of chronic work stress" (Milfont et al., 2007). As a symbol for exhaustion, burnout refers to a fire that loses its intensity or about to fade off. It implies that once a fire was burning but the fire cannot continue because of inadequate resources. Over time, employees experiencing burnout lose the capacity to provide the intense assistance that makes an impact. If they continue working, the result is not burning but worse than that. From their own perspective or that of others, they achieved less. In summary, the metaphor describes the fatigue of employees' competence to maintain an intense involvement that has a meaningful impact at work (Schaufeli et al., 2008). Infrequent feelings of being tired, upset, or inundated with various issues related to an individual's job are widespread. However, when these feelings extend beyond specific instances and last for extended periods of time, an individual may be having indications burnout (Hayes \& Weathington, 2007). Employees in human services organizations have widespread interaction with demanding subpopulations, are more vulnerable to high degrees of burnout (Weisberg, 1994). Maslach and Jackson (1981) argued that, burnout is a kind of syndrome on people who works at people-related jobs, such as emotional exhaustion and cynicism.

Especially in public sector employees are subject to dull and monotonous assignments, team conflicts, anxiety over peer competition, burden of high ambition and family expectations, and uncertainties in the job. All these factors can lead to high job burnout (Singh et al., 2011).

\section{Literature Review}

\subsection{Burnout and Basic Concepts}

The concept of job burnout was first used in the USA during the 1970s to express the state of occupational depression experienced by the people working in the customer services. The concept emerged in the 1961 novel "A Burnt-Out Case" by Greene, which depicts the story of a spiritually tormented and disillusioned architect who quit his job and withdrew to the African jungle and was characterized by "extreme fatigue and the loss of 
idealism and passion for one's job" (Maslach, Schaufeli, \& Leiter, 2000).

The literature contains many studies carried out by researchers trying to explain the certain concepts related to burnout. Cherniss defines the burnout as "psychological withdrawal from work in response to excessive stress and dissatisfaction" and claims that it is kind of a "disease of over-commitment" (Cherniss, 1980).

According to Maslach and Jackson, burnout is a "physical, emotional and mental exhaustion syndrome which derives from chronic physical exhaustion, feelings of helplessness and hopelessness, and development of a negative self-concept as well as negative attitudes towards the profession, the life and the other people" (Maslach \& Jackson, 1981). Before making up a definition for the concept of burnout, it may be useful to use a case study. Burnout may be interpreted as the entire loss suffered by the people within the whole process, rather than the millions of dollars lost each day or monetary loss or workers that are no longer capable of working or functioning. In the recent years, the sign and symptoms of burnout such as employee turnover, absenteeism, inefficiency, psychological problems etc. are observed more frequently in the society. Instead of referring this situation as burnout, we can say that the state of burnout includes all of these signs and symptoms (Vallen, 1993). The literature review shows that there are several definitions of burnout. The most important and frequently used definitions are given below.

Burnout is a complex syndrome including psychosomatic disorder, insomnia, negative attitude towards the job and customers, absenteeism, alcohol and drug use, feeling of guilty, pessimism, lack of attention and depression and is seen as the lack of energy at a considerable level as a result of the energy overuse (Sürgevil, 2006). Burnout can be defined as a result of an abnormal relationship between the person and the work environment (Best et al., 2005).

Burnout, a phenomenon that is of interest for both individuals and organizations, is characterized by decreasing energy, power and resources in the presence of excessive demands. It is one of the factors which influence the affectivity and productivity of the workers and staff in every field.

Burnout is a syndrome with three components called emotional burnout, desensitization and decrease in the feeling of success (Cordes \& Dougherty, 1993).

Beheshtifar (2013) stated in his paper, burnout is "a consequence of the perceived disparity between the demands of the job and the resources (both material and emotional) that an employee has available to him or her".

The concept of burnout became a scientific topic following the studies by Maslach and her colleagues and Cherniss. In today's world, the three-dimensional burnout concept used by Maslach et al. is the most common and accepted definition of burnout. According to this definition, the concept of burnout includes emotional exhaustion, desensitization and reduced sense of personal accomplishment observed in those interacted extensively with other people (Maslach, 1982). Maslach (1982) addresses the burnout concept in three dimensions: emotional exhaustion, depersonalization/cynicism and personal accomplishment/self-efficacy. This definition indicates that burnout is a syndrome showing itself as emotional exhaustion, depersonalization and reduced personal accomplishment that can occur among individuals who do 'people work' of some kind. More specifically, individuals with burnout symptoms feel emotionally overextended and exhausted by their work, show impersonal response toward recipients of their service and experience decline in their feelings of competence and successful achievement in their work. In this respect, Maslach has made the most common definition of burnout (Maslach, 1982). According to Maslach, burnout is a three-dimensional syndrome that can occur among individuals who do 'people work' of some kind. The key point here is the three-dimensional structure of burnout (Maslach, 1982).

This section discusses the basic concepts of burnout. In this respect, the study will focus on three basic concepts.

\subsubsection{Emotional Exhaustion (Stress)}

Emotional exhaustion implies that, the feelings of being emotionally forced to the limits and exhausted experienced by individuals during or after their working hours (Maslach, 1982, p. 118). Emotional exhaustion represents the stress dimension of burnout. It defines the exhaustion of one's both emotional and physical resources. Therefore, the individuals feel themselves tired and worn-out (Sürgevil, 2006, p. 79). Hsieh and Wang (2012) stated that emotional exhaustion can be avoided by reducing stress of "overwork.

\subsubsection{Depersonalization (General Adaptation)}

The second dimension of job burnout, depersonalization, refers to individual's remote, insensitive, stiff and even inhumane attitudes towards the people they work with and the job itself (Baltaş \& Batlaş, 2002). Also term points to an apathetic or a distant manner toward work in general and the peers, losing one's interest in work, and 
feeling that work has lost its attraction. Workers may display an isolated and unemotional insensitivity, and they may be cynical toward coworkers, clients, and the organization (Huang et al., 2012). Depersonalization also causes general adaptation syndrome in the individuals. The individuals show signs threatening the integrity of organism and eventually causing disruption of balance. The individual needs to rebuild the disrupted balance and adapt oneself to the events. Such stress reactions observed in the individuals are called general adaptation syndrome, which is a concept aiming to describe the reactions to stress. General adaptation syndrome has three stages: Alarm reaction, the stage of resistance and the stage of exhaustion (Baltaş \& Batlaş, 2002). Alarm reaction is defined as the immediate reaction to a stressor. Organism goes into a state of shock and counter shock. The individual makes an active physiological attempt to deal with the situation. During the stage of resistance, the individual increases the resistance to stress against the situation; however that resistance may be reduced in other situations. When highly affected by stressful situations, the individual reaches the stage of exhaustion (Baltaş \& Batlaş, 2002).

\subsubsection{Reduced Personal Accomplishment (Job Dissatisfaction)}

Personal accomplishment refers to one's feelings of competence and successful achievement in one's work. Personal failure, on the contrary, refers to the feelings of incompetence and unsuccessful achievement. Individuals suffering from personal failure are full of failure feelings. They adopt a negative way of thinking towards the other people, which also leads to the development of negative self-concept. The negative self-concept is expressed in feelings of guilt. As a result, the individuals get a sense that nobody loves them and experience severe feelings of failure.

Such feelings of failure experienced by the individuals lead to a decrease in the feelings of accomplishment and competence towards the people they work with or they encounter as part of their job. In such situations, individuals cannot make progress in their work and have a feeling of losing ground which finally causes them to feel guilty.

Although considered as job burnout by definition, job dissatisfaction and burnout are in fact different concepts. As a concept defining the depersonalization and the lack of motivation or energy towards the job, job burnout is different from job dissatisfaction (Cordes \& Dougherty, 1993).

\subsection{Reasons of Job Burnout}

There is more than one reason for job burnout. The reasons depend on various conditions. Burnout could be caused by personal or environmental factors. Some of the reasons of job burnout are as follows (Dilsiz, 2006).

Age, Marital Status, Number of children, Over-commitment to work, Expectations from life, Motivation, Personality, Performance, Stress level, Job Satisfaction, Informal support, Support from superiors or subordinates

\subsection{Development of Burnout Process}

The study is based on the Maslach Burnout Inventory and its dimensions i.e., emotional exhaustion, depersonalization and reduced personal accomplishment, which are the focus of many other studies in the literature. According to the Maslach Burnout Inventory, emotional exhaustion occurs as a result of the depletion of individuals' emotional resources by heavy workload. Striving to deal with the work overload, the individuals tend to distance themselves away from other people. This gradually leads to the second stage of burnout, depersonalization. At the final stage, perceiving that such distance attitude they adopted is restricting their contributions to the society or the organization they work in, the workers feel themselves incompetent about their occupational success and human relations, thus having a feeling of reduced personal accomplishment (Cordes \& Dougherty, 1993).

Various researchers suggested some other models as an alternative to the chronological sequence followed in the Maslach Burnout Inventory. Golombiewski's Phase Model, for example, suggests that the burnout process starts with depersonalization, followed by feelings of reduced personal accomplishment and eventually ending with emotional exhaustion. For the emergence of reduced personal accomplishment feeling, the individual should have experienced the depersonalization period, which is also required to experience emotional exhaustion (Cordes \& Dougherty, 1993).

The model developed by Dierendonck et al. (2001) suggests that feeling of reduced personal accomplishment is the first stage of the burnout process. The dimension of reduced personal accomplishment is neither the final stage as in the Maslach Burnout Inventory, nor an intermediate stage between depersonalization and emotional exhaustion as in the Golombiewski's Phase Model. 
Regarding the developmental process of job burnout, another researcher indicates the following: If the worker does not eliminate stress during the course of work, he/she will show a tendency to bring stress into their personal life. Individuals suffering from burnout complain about failure in marital adjustment and family conflicts. The workers want to distance themselves from other people after having an emotionally intensive working day with the clients they provide services. This desire of becoming isolated means neglecting the relations with the family and social environment. Individuals that experience marital conflicts and restrict their relations with their social environment, then see themselves as bad or wrong, eventually finding themselves falling into depression. As a result, they lose potential to help others and strive to protect them (Bahar, 2006).

There are also some other researchers suggesting that developmental process of burnout does not require certain stages and one dimension of burnout is not necessarily the result of the other (Cordes \& Dougherty, 1993).

\subsection{Outcomes of Burnout}

The outcomes of burnout include the changes at the organizational level, lying down on the job, increase in tendency and intention to quit the job, disruption of service quality, absence without leave, tendency to extend the leave by means of sick leave reports etc., decrease in group cohesiveness, increase in physical and emotional symptoms, increase in medical expenditures, family life deterioration, deterioration in human relations (both with colloquies and other people) and inadaptability, indicators of performance fail, job dissatisfaction, tendency to get ill with no reason, increase in occupational injuries and accidents. The most applicable consequences facing the restaurant industry are lowered performance levels and turnover. Because of the constant taxing of emotions, a burned out person will often turn to harsh behavior for temporary relief (Twigg \& Kang, 2011).

Several studies had conducted on burnout were related mostly with stress, fatigue, performance, turnover. In this paper we intend to research the effects of demographic variables on job burnout.

Demographic variables for example: sex, age, marital status, education, and tenure; however, there is still some discussion about the relation of demographic differences with burnout (Chen et al., 2012). Numerous studies have often reported on effects of demographic variable on job burnout. Based on the similarities in their rational and personal attributes are reflected in other studies of gender differences in burnout which also revealed incoherent results. Some studies reported higher level of burnout among women some of them reported higher levels of burnout among men (Ronen \& Ronen, 2008). For instance, Lau et al. (2005) investigated the relationship between teachers' demographic variables and burnout in Hong Kong. Gender differences were found in all three burnout syndromes, whereas age was the strongest predictor for emotional exhaustion and depersonalization (Luk et al., 2010). Maslach and Jackson (1981), found that female employees had higher burnout rate than males at public-related jobs for some factors but not all of them. Also at age differences items there were significant findings on burnout factors. In addition, education factor had a relationship between burnout factors. Brewer and Shapard (2004) had made meta-analysis on the effects of demographic differences on burnout. They found negative correlation between age and experience and burnout. Attafar et al. (2011) made a research on librarians stated that, male librarians suffered from higher degrees of emotional exhaustion and depersonalization, but no significant differences were found in librarians' sense of personal accomplishment based on their gender. Another research conducted by Chen and Kao (2012) stated that two way interaction between burnout and job tenure is found significantly positive. Guthrie and Jones (2012) argued that gender differences effects the burnout process related with job satisfaction and job outcomes. They also implied that, researchers should consider the gender differences between employees on burnout factors before making generalizations. Fernet et al. (2013), also found demographic related results. Gender was negatively associated with social support, but positively with depersonalization, and women reported greater social support and lower depersonalization than men. In addition, age was positively associated with role overload, but negatively with social support and perceived relatedness. Jung (2013), found in his research there was a relationship between depersonalization and gender, marital status, work experience and age.

Although there were several inconsistent results on demographic effects on burnout there were several other studies proving the relation.

Hypothesis

The main goal of this research is to find out the relationship between demographical differences and job burnout. We developed our hypothesis on this aspect as follows:

H1: There is a relationship between employee gender and job burnout;

$\mathrm{H} 2$ : There is a relationship between employee age and job burnout;

H3: There is a relationship between employee work experience and job burnout; 
H4: There is a relationship between employee education and job burnout;

H5: There is a relationship between employee title and job burnout.

\section{Methodology}

\subsection{Research Goal}

In this research we aim to find the effects of demographical differences on staff burnout. To test the assumption one scale was conducted.

\subsection{Sample and Data Collection}

The contributors in the current study comprised 261 public sector institution employees in Ankara in Turkey in December 2013-January 2014. Due to institutions' privacy policy, we could not mention the name of it. We named the institution as "institution X". The institution X included 261 employees and all of them participated to questionnaire. Because of the limited numbers of participants, we tried to cover the whole institution. Questionnaires were spread by the researcher to every participant in different sessions in all of the institution. When the returned questionnaires were examined, 31 were invalid. As a result, a total of 169 valid responses were used in the research. The samples included 51 (30.2\%) female and $118(69.8 \%)$ male volunteers. Their education level was; 28 (16.6\%) high school, 31 (18.3\%) graduate degree, $80(47.3 \%)$ master's degree, and 30 $(17.8 \%)$ doctorate degree. Participants had been working in their jobs; 95 (56.2\%) for $1-10$ years, $30(17.8 \%)$ for 11-20 years, 44 (26\%) for 21-40 years.

\subsection{Analyses and Results}

Data produced in this study were collected by survey. The survey consisted of two measures. In the first part questions about the demographic characteristics of public sector institution X employees; in the other part questions designed to measure staff burnout were asked.

Table 1. Factor analyses

\begin{tabular}{lll}
\hline \multicolumn{1}{c}{ Items } & EE & PA \\
\hline I feel fatigued when I get up in the morning and have to face another day on the job & .851 \\
I feel emotionally drained from my work. & .830 \\
I feel burned out from my work. & .825 \\
I feel used up at the end of the workday. & .804 \\
I feel like I am at the end of my rope. & .693 \\
I feel exhilarated after working closely with my recipients. & .695 \\
I can easily create a relaxed atmosphere with my recipients. & .690 \\
I can easily understand how my recipients feel about things. & .665 \\
I have accomplished many worthwhile things in this job & .643 \\
I deal very effectively with the problems of my recipients & .641 \\
Work with people all day is really a strain for me. & .882 \\
I've become more callous toward people since I took this job. & .722 \\
\hline
\end{tabular}

Note. EE (Emotional Exhaustion, PA: Personnel Achievement, DP: Depersonalization).

Job burnout was measured by Maslach Burnout Inventory which has been proven to be a reliable and valid instrument of burnout The measure included 22 items, each item was answered through a five-point Likert scale ranging from " $1=$ strongly disagree" to " $5=$ strongly agree." In the present study, the Cronbach's alpha coefficient for the scale was .81 .

The correlations between research variables listed below in Table 2. There is a positive relationship between depersonalization title and education, negative relationship age and gender. We could not find any relation between demographical variables and emotional exhaustion and personnel achievement. We also found that there were a negative correlation between education, age and experience and positive correlation between age and experience. In addition, we found negative correlation between title and age. 
Table 2. Correlations

\begin{tabular}{|c|c|c|c|c|c|c|c|c|}
\hline Scale & 1 & 2 & 3 & 4 & 5 & 6 & 7 & 8 \\
\hline 1. $\mathrm{EE}$ & $(.89)$ & & & & & & & \\
\hline 2. $\mathrm{PA}$ & 0.0 & $(.90)$ & & & & & & \\
\hline 3. DP & 0.0 & .00 & $(.91)$ & & & & & \\
\hline 4. TITLE & .40 & -.20 & $.18^{*}$ & $(.88)$ & & & & \\
\hline 5. EDUCA & .40 & -.01 & $.15^{*}$ & $-.01 *$ & $(.81)$ & & & \\
\hline 6. AGE & -.01 & -.13 & $-.32 * *$ & $-.15^{*}$ & $-.29 * *$ & $(.79)$ & & \\
\hline 7. EXPER & -.92 & -.08 & $-.17 *$ & -.14 & $-.32 * *$ & $.67 * *$ & $(.78)$ & \\
\hline 8. GENDER & -.62 & -.10 & .61 & -.59 & .13 & .07 & .54 & $(.78)$ \\
\hline
\end{tabular}

Note. ${ }^{*} \mathrm{p}<0.05 ;{ }^{*} \mathrm{p}<0.01 ;$ EE (Emotional Exhaustion, PA: Personnel Achievement, DP: Depersonalization).

To explore whether the independent variables had a significant impact on the dependent variables, hierarchical regression analyzes were conducted. Table 3 shows the regression analysis results for each burnout dimension. In the regression analysis, demographic variables (title, education, age, experience and gender) were entered to control their effects, on emotional exhaustion, personnel achievement and depersonalization. The results show that, age had a negative and title had a positive and significant effect on depersonalization.

Table 3. Hierarchical regression analyses

\begin{tabular}{cccc}
\hline Dependent & EE & PA & DP \\
\hline Title & $\boldsymbol{\beta}$ & $\boldsymbol{\beta}$ & $\boldsymbol{\beta}$ \\
Education & 0.28 & -0.49 & $0.13^{*}$ \\
Age & -0.59 & -0.47 & 0.07 \\
Experience & 0.11 & -0.14 & $-0.36^{* *}$ \\
Gender & -0.18 & -0.002 & 0.10 \\
$\Delta \mathbf{R}^{2}$ & -0.11 & -.089 & 0.07 \\
$\Delta \mathbf{F}$ & 0.176 & 0.138 & 0.123 \\
\hline
\end{tabular}

Thus, hypotheses $\mathrm{H} 2$ (There is a relationship between employee age and job burnout) $(\beta:-0.36, \mathrm{p}<0.001)$ and $\mathrm{H} 5$ (There is a relationship between employee title and job burnout) $(\beta: 0.13, \mathrm{p}<0.05)$ accepted $\mathrm{H} 1$ (There is a relationship between employee gender and job burnout), H3 (There is a relationship between employee work experience and job burnout), $\mathrm{H} 4$ (There is a relationship between employee education and job burnout) were rejected.

\section{Conclusion}

The aim of this paper is to explore the effects of demographical differences on job burnout. Burnout is a phenomenon which exists in nearly every workplace, revealed in literature by all aspects. Although it is commonly known by managers and supervisors there is not enough intention to prevent or reduce it. Especially in public sector there are strict rules for almost everything. The organization climate is not allows (commonly not every one of them) the employees to react changing environment. The burnout is nearly inevitable for these kinds of organizations. The main purpose of this paper is to examine the effects of demographical differences on job burnout in public sector.

After the explanatory factor analyses we found tree factors explaining the burnout. The first factor named "Emotional exhaustion", the second factor was named "Personnel accomplishment" and third factor named as a "Depersonalization". Demographical variables are age, gender, experience, title and education. As a result of correlation analyses we found that, there is a positive relationship between depersonalization, title $(\mathrm{r}=.18, \mathrm{p}<.05)$, and education $(\mathrm{r}=.15, \mathrm{p}<.05)$, negative relationship with age $(\mathrm{r}=-.32, \mathrm{p}<.05)$ and gender $(\mathrm{r}=.17, \mathrm{p}<.05)$. We also 
found that there were a negative correlation between education, age and experience and positive correlation between age and experience. In addition we found negative correlation between title and age. We could not find any relation between demographical variables and emotional exhaustion and personnel achievement. As a result of regression analyses, demographic variables (title, education, age, experience and gender) were entered to control their effects, after which emotional exhaustion, personnel achievement and depersonalization. The results show that, title had a positive and significant effect $(\beta: 0.13, \mathrm{p}<0.05)$ and age had a negative and significant effect on depersonalization $(\beta$ : $-0.36, \mathrm{p}<0.001)$. We examined the earlier studies about the demographic differences effects on burnout. There were several of them some of them found a relation between them some of them couldn't. In this research we found a positive relation on title and negative relation between depersonalization and age. This finding leads us to think about the employees title effect the burnout level, when the responsibilities get higher with the title, job complexity goes higher. Especially in public sector, titles become more important than any other sector. The age had a negative relation between burnout. This finding explains that, older people developed a kind of immunity to the burnout and the young employees are suffering from burnout much more than older employees.

\section{Limitations and Future Research}

This paper focused on demographic factors on staff burnout such as gender, age, tenure. This was very limited scope on the basis of burnout. Without any doubt, these findings are limited by the sample and the assessment instruments used in the present study. This research conducted on public sector employees in Turkey; the findings might not be transferable to other organizations. The fact that the present sample is composed of only 261 personnel is another drawback of this study.

We conducted this research on a public sector institution, it is recommended that further researches can be conducted on different sectors and also in different countries for the generalizability of the results. Moreover, the Maslach burnout inventory was used for as a scale. Researchers could use different and more recent scales developed by qualified academicians. The research focused on demographic factors, researchers could widen the relative subjects such as job satisfaction, work-life conflict, emotional IQ or cultural IQ.

\section{References}

Angerer, J. M. (2003). Job Burnout. Journal of Employment Counseling, 40(3), 98-107.

Attafar, A., Nastaran, S. A., \& Arash, S. (2011). Effects of Demographic and Personal Factors on Job Burnout: An Empirical Study in Iran. International Journal of Management, 28(4), 275-286.

Baltaş, A., \& Baltaş, Z. (2002). Stres ve başa çıkma yolları. İstanbul: Remzi Yayınevi.

Brewer, E. W., \& Leslie, S. (2004). Employee Burnout: A Meta-Analysis of the Relationship between Age or Years of Experience. Human Resource Development Review, 3(2), 102-123. http://dx.doi.org/10.1177/1534484304263335

Bahar, E. (2006). Tükenmişlik sendromu, otel işletmelerinde ön büro çalı̧̧anlarında bir uygulama. Adnan Menderes Üniversitesi sosyal Bilimler Enstitüsü Turizm İşletmeciliği Anabilim Dalı. Yayımlanmamış Yüksek Lisans Tezi.

Beheshtifar, M., \& Omidvar, A. R. (2013). Causes to Create Job Burnout in Organizations. International Journal of Academic Research in Business and Social Sciences, 3(6), 107-113.

Best, R. G., Laura, M. S., \& Ronald, G. D. (2005). Core Self-Evaluations and Job Burnout: The Test of Alternative Models. Journal of Occupational Health Psychology, 10(4), 441-451. http://dx.doi.org/10.1037/1076-8998.10.4.441

Chen, C. F., \& Kao, Y. L. (2012). Moderating effects of work engagement and job tenure on burnout-performance among flight attendants. Journal of Air Transport Management, 25, 61-63, http://dx.doi.org/10.1016/j.jairtraman.2012.08.009

Chen, H., Peng, W., \& Wei, W. (2012). New Perspective On Job Burnout: Exploring The Root Cause Beyond General Antecedents Analysis. Psychological Reports, 110(3), 801-819. http://dx.doi.org/10.2466/01.09.13.PR0.110.3.801-819

Cherniss, C. (1980). Staff Burnout: Job stress in the human services. Beverly Hills, CA: Sage.

Cordes, C. L., \& Dougherty, T. W. (1993). A rewiev and an integration of research on job burnout. Academy of Management Rewove, 18(4), 621-656.

Dilsiz, B. (2006). Konya ilinde ki ortaöğretim okullarında çalışan öğretmenlerin tükenmişlik ve iş doyumu 
düzeylerinin bölgelere göre değerlendirilmesinin çok değişkenli istatistiksel analizi. Selçuk Üniversitesi Fen Bilimleri Enstitüsü İstatistik Anabilim Dalı. Yayımlanmamış Yüksek Lisans Tezi.

Dierendonck, D. V., \& William, B. S. (2001). Burnout and InequityAmong Human Service Professionals: A Longitidunal Study. Journal of Occupational Health Psychology, 6(1), 43-52. http://dx.doi.org/10.1037/1076-8998.6.1.43

Eren, V., \& Durna, U. (2006). Üç boyutlu bir yaklaşım olarak örgütsel tükenme. Selçuk Üniversitesi Karaman I.I. ..B.F. Dergisi, 10(9), 40-51.

Fernet, C., Stéphanie, A., Trépanier, S. G., \& Dussault, M. (2013). How do job characteristics contribute to burnout? Exploring the distinct mediating roles of perceived autonomy, competence, and relatedness. European Journal of Work and Organizational Psychology, 22(2), 123-137. http://dx.doi.org/10.1080/1359432X.2011.632161

Gençer, A. (2002). Öğretmenlerin iş doyumu ile mesleki tükenmişlik düzeyleri arasındaki ilişskiler. Eskişehir Osmangazi Üniversitesi Sosyal Bilimler Enstitüsü Eğitim Bilimleri Anabilim Dalı. Yayımlanmamış Yüksek Lisans Tezi.

Guthrie, C., \& Ambrose, J. (2012). Job Burnout in Public Accounting: Understanding Gender Differences. Journal Of Managerial Issues, 24(4), 390-411.

Hayes, C. T., \& Weathington, B. L. (2007). Optimism, Stress, Life Satisfaction, and Job Burnout in Restaurant Managers. The Journal of Psychology, 141(6), 565-579. http://dx.doi.org/10.3200/JRLP.141.6.565-580

Hsieh, Y. H., \& Wang, M. L. (2012). The Moderating Role of Personality in HRM-from the Influence of JobStress on Job Burnout Perspective. International Management Review, 8(2), 1-15.

Huang, Y. H., Chenb, C. H., Duc, P. L., \& Huangd, I. C. (2012). The causal relationships between job characteristics, burnout, and psychological health: a two-wave panel study. The International Journal of Human Resource Management, 23(10), 2108-2125. http://dx.doi.org/10.1080/09585192.2011.610934

Jung, E. (2013). Work Stress and Burnout: The Mediating Role of Mood Regulation among Information Technology Professionals. Journal of Workplace Behavioral Health, 28, 94-106. http://dx.doi.org/10.1080/15555240.2013.779502

Koçel, T. (2005). İşletme yöneticiliği, yönetim ve organizasyon, organizasyonlarda davranış, klasik-modern-çağdaş ve güncel yaklaşımlar (10. Baskı). İstanbul: Arıkan Basım Yayım Dağıtım.

Luk, A. L., Bessie, P. S. C., Selwyne, W. C., \& Stanley, K. K. K. (2010). An Exploration of the Burnout Situation on Teachers in Two Schools in Macau. Soc Indic Res, 95, 489-502. http://dx.doi.org/10.1007/s11205-009-9533-7

Maslach, C., Schaufeli, W. B., \& Leiter, M. P. (1982). Job burnout. Annu. Rev. Psychol, 52, 397-422. http://dx.doi.org/10.1146/annurev.psych.52.1.397

Maslach, C., \& Jackson, S. E. (1981). The Measurement of Experienced Burnout. Journal of Occupational Behavior, 2, 99-113. http://dx.doi.org/10.1002/job.4030020205

Milfont, T. L., Simon, D., Shanthi, A., Elizabeth, R., \& Sally, M. (2007). Burnout and Wellbeing: Testing the Copenhagen Burnout Inventory in New Zealand Teachers. Soc Indic Res, 89, 169-177. http://dx.doi.org/10.1007/s11205-007-9229-9

Ronen, S., \& Ayala, M. R. (2008). Gender differences in engineers' burnout. Equal Opportunities International, 27(8), 677-691. http://dx.doi.org/10.1108/02610150810916749

Schaufeli, W. B., Michael, P. L., \& Christina, M. (2008). Burnout: 35 Years of Research And Practice. Career Development International, 14(3), 204-220. http://dx.doi.org/10.1108/13620430910966406

Singh, P., Damodar, S., \& Michael, P. L. (2011). Antecedents, Work-Related Consequences, and Buffers of Job Burnout Among Indian Software Developers. Journal of Leadership \& Organizational Studies, 19(1), 83-104. http://dx.doi.org/10.1177/1548051811429572

Sürgevil, O. (2006). Çalışma Hayatında Tükenmişlik Sendromu Tükenmişlikle Mücadele Teknikleri. Ankara: Nobel Yayın Dağıtım.

Twigg, N. W., \& Bomi, K. (2011). The effect of leadership, perceived support, idealism, and self esteem on burnout. Journal of Behavioral Studies in Business, 4, 1-20.

Valen, G. K. (1993). Organizational climate and burnout. The Cornell Hotel and Restaurant Administration 
Quarterly, 34(1), 31-36.

Yıldırım, F. (1996). Banka çalışanlarında iş doyumu ve algılanan rol çatışması ile tükenmişlik arasındaki ilişki. Hacettepe Üniversitesi Sosyal Bilimler Enstitüsü Psikoloji Ana Bilim Dalı. Yayımlanmamış Yüksek Lisans Tezi.

Vallen, G. K. (1993). Organizational climate and burnout. The Cornell Hotel and Restaurant Administration Quarterly, 34(1), 54-59.

Weisberg, J. (1994). Measuring workers' burnout and intention to leave. International Journal of Manpower, 4, $1-7$.

\section{Appendix}

Appendix A. MBI Human Service Survey

1. I feel emotionally drained from my work.

2. I feel used up at the end of the workday.

3. I feel fatigued when I get up in the morning and have to face another day on the job.

4. I can easily understand how my recipients feel about things.

5. I feel I treat some recipients as if they were impersonal objects.

6. Work with people all day is really a strain for me.

7. I deal very effectively with the problems of my recipients.

8. I feel burned out from my work.

9. I feel I'm positively influencing other people's lives through my work.

10. I've become more callous toward people since I took this job.

11. I worry that this job is hardening me emotionally.

12. I feel very energetic.

13. I feel frustrated by my job.

14. I feel I'm working too hard on my job.

15. I don't really care what happens to some recipients.

16. Working with people directly puts too much stress on me.

17. I can easily create a relaxed atmosphere with my recipients.

18. I feel exhilarated after working closely with my recipients.

19. I have accomplished many worthwhile things in this job.

20. I feel like I am at the end of my rope.

21. In my work, I deal with emotional problems very calmly.

22. I feel recipients blame me for some of their problems.

\section{Copyrights}

Copyright for this article is retained by the author(s), with first publication rights granted to the journal.

This is an open-access article distributed under the terms and conditions of the Creative Commons Attribution license (http://creativecommons.org/licenses/by/3.0/). 